\title{
From Acceptance to "Othering": An Analysis of Swedish Changing Identity towards the Refugees and Muslim Minority Groups
}

\author{
Radityo Dharmaputra \\ University of Tartu \\ Reza Akbar Felayati and Yohanes Putra Suhito \\ Universitas Airlangga
}

\begin{abstract}
By using the case study of Sweden and the momentum of the refugee crisis in Europe, this research attempts to analyse the extent to which the shifting practice of Swedish policy towards the refugees (as signified by the new 2016 law prohibiting/restricting the entrance of refugees) might prompt some forms of core identity changes related to immigrant and minority groups. Using the poststructuralism as the central perspective on identity, we argue that the flow of refugee during the crisis in 2015-2016 could be classified as an external shock which then compelled a changing practice of Swedish refugee policy. We then try to show the relationship between changing practice and changing identity discourse by tracing the dynamics of the attitude and perception from both the Swedish government and society regarding the refugees and the Muslim minority groups in Sweden. By analysing the main texts in Swedish identity discourses and the media/public discourses, we found that the changing policy reconstitutes (albeit slowly) the identity of Sweden in "othering" the refugees and Muslim minority groups. This kind of "Self/Other" relationship was different from the condition before and during the early days of the refugee crisis.
\end{abstract}

Keywords: the European refugee crisis, Sweden, Muslim Minority Groups, PostStructuralism, Changing Practices/Discourses.

Dengan menggunakan studi kasus Swedia dan momentum krisis pengungsi di Eropa, penelitian ini berupaya menganalisis sejauh mana praktik pergeseran kebijakan Swedia terhadap para pengungsi (sebagaimana ditandai oleh undang-undang baru tahun 2016 yang melarang atau membatasi pintu masuk bagi pengungsi) mungkin mendorong beberapa bentuk perubahan identitas inti yang terkait dengan kelompok imigran dan minoritas. Dengan menggunakan poststrukturalisme sebagai perspektif utama tentang identitas, penulis berpendapat bahwa masuknya pengungsi selama krisis pada tahun 2015-2016 dapat diklasifikasikan sebagai guncangan eksternal yang kemudian mendorong perubahan kebijakan kebijakan pengungsi Swedia. Kami kemudian mencoba menunjukkan hubungan antara praktik yang berubah dan perubahan diskursus identitas dengan menelusuri dinamika tingkah laku dan persepsi dari pemerintah Swedia dan masyarakat terhadap pengungsi dan kelompok minoritas Muslim di Swedia. Dengan menganalisis teks-teks utama dalam diskursus identitas Swedia dan diskursus media atau publik, penulis menemukan bahwa kebijakan yang berubah merekonstruksi (walaupun perlahan-lahan) identitas Swedia dalam "othering" para pengungsi dan kelompok minoritas Muslim. Hubungan "self/other" semacam ini berbeda dengan kondisi sebelum dan selama masa-masa awal krisis pengungsi.

Kata-kata kunci: Krisis pengungsi Eropa, Swedia, Kelompok Minoritas Muslim, Poststructuralism, perubahan praktik/diskursus. 
Sweden has been known as a nation-state that ranks first in the implementation of immigrant integration programs and policies that best meet the standards of the Migrant Integration Policy Index (MIPEX), making it one of Europe's most liberal nation-states compared to other European countries. However, the refugee crisis in Europe has pushed Sweden into a country with stricter and closer immigration policies. This tendency is proved by the ratification of the Draft Law (Bill) on the tightening and restriction of refugees and asylum seekers in July 2016 (Migrationsversket 2016).

This indication of a shift is staggering, especially in the historical and cultural aspect, since Sweden always put forward the integrative aspect in responding to refugee and minority issues. This integrative aspect is demonstrated by the Swedish Integration Policy which puts forward the values, obligations, and equal opportunities for all refugees and asylum seekers in Sweden. This policy encourages individuals to support and participate in maintaining fundamental democratic values, contributing to equal rights and opportunities for all while preventing and combating ethnic, xenophobia and racism discrimination against immigrants, refugees, and asylum seekers (Wiesbrock 2011).

However, by the emergence of stricter refugee policies, the authors perceive that Sweden has experienced a fundamental political turn. On this occasion, using poststructuralism, the authors try to see how far the refugee crisis occurred in Europe has been transformed into an external shock which stimulated the shift of Sweden's immigration policy. The authors also seek the link between changing practice and Swedish identity discourse through the dynamics of Swedish perceptions and actions towards refugees and Muslim minorities in the country.

Using the method of poststructuralist discourse analysis, focusing primarily on the primary official documents associated with the Swedish identity discourse, the authors find that the shift in actual policies after 2016 encourages the emergence of new identity discourse in Sweden. This discourse has labelled refugees and Muslim minority groups as "others". The initial findings on this "Self/Others" relations contrast with Swedish immigration policies that tended to be integrative. Furthermore, this relation could affect the discursive structure in Sweden, resulting in a transformation of identity within the Swedish discursive structure. This indication is characterised by several acts of violence against refugees as well as the destruction of Islamic religious symbols.

This research has become essential and urgent, exemplified by the idea that the refugee crisis in Europe can affect the identity of an open and inclusive country such as Sweden. This wave of refugee crisis might mark the end of an era when Europe (especially Northern Europe) is considered a beacon on human rights issues. Furthermore, if policies can change the fundamental identity of society, this study can also contribute theoretically to an understanding of the relationship between identity discourse and practice.

\section{Theoretical Frameworks}

Identity has become one of the main concepts in IR. As Burke pointed out (2006, 394), "there is no world politics without identity". However, Brubaker and Cooper (2000) have warned that the utilization of the concept of "identity" often triggers new problems, because of the overlapping role between "identity" as an analytical concept and/or practical concept. For that reason, in this study, we use "identity" as an analytical concept by taking the basic definition according to Kowert, Campbell, and Urrestarazu. According to Kowert (1998), one of the main dimensions of identity 
is "inside/outside", or when using the term Urrestarazu (2015) is "Self" and "Other". This distinction or "othering" in Campbell's terminology (1990), is a crucial feature of the concept of identity.

On the discussion of the refugee crisis, the authors find several studies that had attempted to analyse the phenomenon from several theoretical frameworks. Gometz (2016) used the biopolitics approach in explaining the phenomenon of the Syrian refugee crisis in Sweden and analysed that the shift in Swedish government action in dealing with refugees in the country occurred because of the government's interest in standardizing the biological quality of its population and this was done to ensure further Swedish growth in the capitalist system. On the other hand, Borisenko (2016) used social constructivism in his analysis and emphasised the discourse created by the mass media as the main factor that created intersubjectivity regarding the identity of the Syrian refugees. Furthermore, Vertiachykh and Lindroth (2016) used a powerperspective approach in explaining the refugee phenomenon in Sweden, arguing that the Swedish government's subjective refutation of the refugee reception system was considered genuine and false. The problem with these previous studies is that no one has seen whether the policy shifts made by the Swedish government are linked to Swedish identity as an open and inclusive country. This potential linkage is what this research seeks to explore.

\section{Post-structuralism, Identity, and Policy}

Concerning the discussions surrounding the Self-and-Other and the aspects of praxis and ideational, this study uses the post-structuralist approach. This approach argues that both material ideas and praxis/actions are an essential part of an analysis, and both are founded in discourses. As Hansen (2006) argued, both ideas and matter are constructed by discourse, which provides meanings by formulating themselves on a set of knowledge systems and being realised through language. According to Hansen (2006), language and linguistic aspects are comprehended as an inherently unstable system in the socio-political world, in which both can construct a particular identity simultaneously (Hansen 2006). In other words, language and discourse in the knowledge system of the society can analyse the basic actions and ideas in society. This argument is supported by Belsey (1994), who argued that the substance of poststructuralism is a system of knowledge which defines the actions and ideas of society, including the individuals within them. In other words, a system of knowledge in the form of discourse must precede the complete form of ideas and actions carried out within a society. Individuals and society will not be able to think beyond what they have learned from the discursive system, which has shaped their knowledge.

Post-structuralism understands that ideational and material factors do not stand any meaning without the existence of one another. Furthermore, for post-structuralists, language has an essential role in terms of social and politics since language construction enables everything from containing particular meaning to expressing identity. However, what needs to be underlined is the fact that language is a socio-political practice, not a transparent tool used empirically so that the real results in any language does not have an objective truth (Saphiro 1981 in Hansen 2006).

Therefore, identity is formed by the process of associating and differentiating. These are the main processes in constructing an identity narrative. Post-structuralism understands the concept of foreign policy as a discursive practice in which policy and identity are strongly connected in an ontological manner. On the one hand, identity will turn into a holistic 'identity' via realising the discourse and practice of the foreign policy. On the other, identity is constructed as one of the means to achieve legitimacy in foreign policy (Hansen 2006). A similar argument is presented by Campbell (1990), 
who said that foreign policy is a differentiation practice which constitutes the object to be different from the rests of them. In other words, foreign policy is a constitutive practice of identity reproduction, which is constructed by the dominant discourse in each country. Thus, the constructed identity by language aspect and the dominant linguistics circulating within the domestic sphere becomes one of the main reasons behind the making of the foreign policy of a country. However, the identity is produced or reproduced by discourses in the making of the foreign policy concerned.

Regarding identity and discourse as well as its relations with foreign policy, Waever (2002) argued that identity lies within a layered discursive structure, and the deeper the layer becomes, the more difficult it is to politicise or to change it. Accordingly, it is a matter of how much pressure is required and what political costs emerged in the event of such discursive change (Waever 2002). Any change in the surface layer (the praxis level) can affect each other at a deeper level.

Based on the theoretical framework, this paper investigates the possibility of a shift in discourse and perception of refugees, as seen from the shifting of Swedish foreign policy on accepting refugees in 2016. Based on the arguments of Hansen and Campbell, the authors analyse the discourses developed and related to refugees before 2011, and upon 2016, when refugee crisis occurred in Europe and law on refugees was ratified in Sweden. Those discourses are analysed to find the shifting policy which possibly occurs in Sweden and the possibility of shifting identity, as well.

\section{Rethinking Religious Freedom: Conceptual Background}

According to Sakaranaho (2006), the concept of religious freedom has been debated, especially in Europe as its area has developed into a multicultural and plural area in religion. Nevertheless, Sakaranaho (2006) argued that there are two varieties of religious freedom: positive freedom and negative freedom. He stated that positive religious freedom is the right of individuals and communities to believe and behave according to their faith. Whereas negative religious freedom is the right to be independent of religion, not religious, and not engage in any religious activity. Furthermore, it is necessary to understand the difference between the right to have religion and practise the faith (Adrian 2016, 47). Adrian (2016) then made an important note that although many countries in Europe use the rhetoric of religious freedom, they mean the right to hold a particular belief. The dilemma will occur when believers need to perform certain obligations because of their religion, as demonstrated by the halal food phenomenon that generated polemics in many European countries. Therefore, it is necessary in the next section to look at the cases when the government has given religious freedom rhetoric, but then avoid the further exercise of freedom.

There are several models of understanding freedom of religion from the perspective of the state (Sakaranaho 2006). The first model emphasises the same religious position, regardless of the historical background or cultural relation to society. This model requires equal treatment of every religion of the country, without any privileges. The second model, which he uses as the primary model to explain conditions in Ireland and Finland, is a model that extends the privileges the majority receive to other religious groups. A third model is a form that seeks to limit the extension of privileges and divide the two into groups that can meet the criteria set by the state. Sakaranaho $(2006,119)$ argues that in the ever-increasing tension between Islam and the West, a third model or better known as a protectionist model in which states try to apply criteria in economic, political and security aspects before extending such privileges.

Furthermore, Sakaranaho $(2006,119)$ hypothesised that the social recognition of the people is the main factor that could influence the state's desire to protect the rights 
of religious minorities. Following the argument, the phenomenon that occurred in Sweden indicates differences in the recognition of religious minority groups. The introduction of different communities can then influence the choice of models: a stronger community introduction will move the pendulum toward a more substantial extension of privilege (second model), while lower recognition will create a more limited version (third model).

However, the discussion of the model described by Sakaraho cannot explain the people's choice to recognise the existence of minority religions. We argue that Agius's analysis of self-identity can guide understanding of it. Agius (2013) argues that the essential identity discourse and the emergence of a crisis show that Sweden's efforts to engage in the discourse of their binary identity (Swedish Muslims) have shaped the debate over the religious practices of the minority. In this paper, the rhetorical identity discourse used by the Swedish government, especially regarding the "differences" between their values and the values of religious minorities, is analysed in the next section.

In summary, this section deals with three things. First, Sweden may have promoted the idea of religious freedom in their official documents, but the extent to which they allow the exercise of religion may be different. This distinction, coupled with government support for religious minorities, will show how strongly people's recognition of minority religions is. Instead, the recognition of this society will be related to the discourse of identity will emerge and compete during the crisis period. This study then uses several issues to determine the types of religious freedom given to the groups, governmental supports, community recognition, and the competing discourses around all issues.

\section{Methodological Frameworks}

This study is interpretive research which emphasises the understanding of the social meanings contained in international politics (Lamont 2015). In contrast to empiricist/ explanative research, this research does not emphasise the observation and testing of hypotheses, but rather the search for an understanding of identity, ideas, norms, and cultures concerning international politics.

Therefore, this research uses a poststructuralist discourse analysis method in IR, developed by Hansen (2006) and Waever (2002). According to Hansen (2012, 95), the poststructuralist view emphasises policy as a discursive practice and then analyses how the actor constructs a policy and through that policy, the identity. Discourse, as described by Holzscheiter (2014), is the space where man seeks to understand the world and attach meaning to material aspects. Discourses are structured in the form of binary opposition, explaining which subjects are entitled to "speak" and "act", and give limits on what can be said and done (Miliken 1999, 229). This structure of meaning can be used to explain policy (Waever 2002).

In formulating the research design, Hansen $(2006,67)$ explains that there are several issues to be considered. First, how many "Self" and "Other" will be seen? In this study, we look at relations between Sweden as a "Self" unit, and try to examine whether "Sweden" is constructed against "refugees" or "Muslims" as "Others". As the Waever (2002) argument, the discursive meaning of "Self" usually also involves a distinction other than "Self/Other". Instead of threatening and radically different (which, according to Hansen, would be easier to identify), Waever $(2002,24)$ suggests other characteristics such as "friends and relatives". Therefore, relations between Sweden with "refugees" and "Muslim minorities" are also categorised in the "friends/relatives" trajectory. 
The second issue is the issue of which intertextual model used. In his work, Hansen $(2006,57)$ proposes several models based on the intertextuality of official discourse, wider debate, cultural representation, and marginal discourse. In this research, we use Model 1 (official) and Model 2 (wider debate). For official discourse, we focus on official documents from the Ministry of Foreign Affairs, the leader's speech (collected from his official website), and possibly speeches by other prominent members of the government on immigration policy issues. For a broader debate, we examine in-depth the discourse that appears in the mainstream media in the English language, such as The Local and Scandinavia Now, as well as in Swedish such as Svenska Dagbladet.

According to Hansen (2006), several question formulations can be used in poststructuralist discourse analysis. According to Hansen (2006), several question formulations are available in poststructuralist discourse analysis. The focus is what associated with articulations in the official discourse, and how it relates to other discourse (opposition and critical) constructed. The main question is whether "Sweden" as "Self" sees "refugees" and "Muslim minorities" in a superior, inferior, or equally positioned frame. This position may be explicitly articulated, or done by emphasising Sweden's position as "Self". It is also important to note if refugees and Muslim minority groups perceived as threats, friends, strangers, or underdeveloped subjects who need help (Hansen 2006, 68). In this analysis, discursive encounters, references to "Western/ Eastern" may also emerge, compared to Western or European.

Related to the period of the study, the research team used a short timeline, following the guidance of Hansen (2006). Using the 2015 timeframe (beginning of the migrant crisis in Europe) until July 2016 (the issuance of new rules on migration in Sweden), and comparing it with the 2016-2017 timeframe, this study emphasises the temporality aspect, aimed at looking at possible shifts in identity.

\section{Reconsidering Religious Freedom for Minorities: Swedish Policies on Muslim Minorities}

The relation between Islam and the West had always been an intriguing subject, ever since Huntington formulated the "Clash of Civilization" in 1993. One major event that prompted the use of this idea was the Cartoon Crisis in Denmark and Sweden. ${ }^{1}$ As Agius $(2013,242)$ noted, many scholars had used the concept of civilizational conflict to explain the crisis. The subsequent debate moved to the issue of whether Muslim communities could accept the Western values such as the notion of freedom, as the editor of Jyllands-Posten Flemming Rose said in 2005 (Powers 2008, 343). ${ }^{2}$ The response from Muslim communities around the world, from protests ${ }^{3}$, boycott ${ }^{4}$, and bombings ${ }^{5}$, had only underlined the alleged tension between Muslim and the West.

1 The most debated crisis in the one in Denmark, with the focus on Jyllands-Posten cartoon. In Sweden, similar crisis happened after Lars Vilks published his cartoony version of Prophet Muhammad in 2007 (RFE/RL 2012)

2 See, for example, the debate about freedom of expression from different perspective by Rostbøll (2009)

3 For the details on the protests, see Baroud (2006) or Financial Times (2006).

4 For the explanation on the boycott, see Agra Europe (2006); NPR News (2006); or Knudsen et al. (2008)

5 The Report shows that the bomber had been raged by Vilks' satirized drawings of the Prophet (The Economist 2010) 
This tension was intensified by the current refugee crisis faced by Europe. This refugee crisis had transformed into the possible conflict of relations between Islam and the West, due to the majorities of the refugees came from Muslim-majority countries such as Syria (LA Times 2015). The discussion had reappeared about the growing problem of the Muslim population in Europe and the potential Islamisation of Europe (Igler 2015). This increasing concern, intensified after the cartoon crisis, was further aggravated after the Charlie Hebdo shootings in France (2015). As ABC News (2015) had reported, many anti-immigrant protests had occurred in Europe for the last year. The incident of rape in Cologne further intensified the spotlight on a refugee from Islamic cultural background, which then prompted response such as the Pegida's call for massive antiimmigrant demonstrations (The Independent 2016). These contemporary conditions underline the need to reflect on how countries in Europe dealt with their Muslimminorities and how they approached the issue of the rights of minorities under the growing tension. Sweden, regarded as the haven for immigrant and asylum seekers ${ }^{6}$, has been the leading destination for many people during the influx of these Syrian refugees (BBC News 2015a).

Still, Sweden takes a moderate position regarding religious freedom, especially regarding religious minorities. In Sweden, the government have explained their decision allowing the supposedly-halal chicken in some school, to counter some criticism from right-wing Sweden Democrats (The Local Sweden 2015a). This latest issue of halal food, combined with the different response from the government related to the cartoon crisis ${ }^{7}$ showed that both countries had different perception regarding freedom, religion, and religious minorities. This paper focuses on these differences and tries to elaborate the reason why these differences occur, even though the initial assumption based on the homogeneity, the demography, and the principle of civil liberties are quite similar.

Sweden, under the Instrument of Government, Chapter 2, Article 1, regarding fundamental rights and freedom, granted the freedom of worship to practice one's religion. According to this official stance, they respected the freedom to exercise religion, whatever their religion is. The current statement on the official website strengthens these constitutional positions. Sweden promoted their 1951 acknowledgement of religious freedom; the facts that they always had strong majority votes regarding the rights to practise religion; and their high-rank in surveys about religious freedom (Swedish Institute 2015).

Furthermore, Sweden had no law regarding the official state religion. According to the Swedish government official website, the Evangelical Lutheran Church of Sweden had been separated from the state since 2000, making Sweden the only Nordic countries without official religion (Swedish Institute 2015). The consequence of this separation is the absence of any privilege to any religion, thereby making it equal for every religion. This condition follows not only the second model (where the state tries to expand the previous privilege) but moves closer towards the first model of perfect equality. In this sense, the societal recognition to the religious minorities will be higher due to the use of the discourse of cooperation, unity, and good relationship.

\footnotetext{
6 According to the Swedish Government, they have been receiving migrant since the 1850s. However, recent developments had suggested that the Swedish government are currently backtracking, planning tougher rules and border control (Sputnik 2015; NPR News 2015).

7 Danish government initially responded by focusing on the issue of "freedom of speech", made the case a "good" against "evil" struggle between the "good" Danish values and the "evil" Islamist values. In Sweden, the government responded by stating their apologies and reiterating the Swedish principles of "people from different faiths could live side by side" (Turkish Weekly 2007).
} 
In 2009, Muslim Association of Sweden, through its chairperson Mahmoud Aldebe, had called for the Swedish government to legalise the halal and kosher slaughter without stunning the animals by using electroshock (The Local Sweden 2009). Aldebe had called for the ban, which has been in force since 1937, to be revoked due to the right of religious freedom. However, this issue did not become the national concern in Sweden, until 2013, where some angry parents reported a school in Svedala to the inspectorate because the school served halal chicken (The Local Sweden 2013a).

The parents did not argue about "Swedish values" and how "different" is their values from the Muslim minorities. Instead, they argued about the principle of religionneutral education. Even though this issue had sparked debates in the social media, the government responded to this issue by stating that the law does not regulate the methods of slaughter used for the meat in schools (The Local Sweden 2013b). As highlighted by the most current news regarding the halal foods, both the government and the local society in Sweden seemed to accept the religious freedom of Muslim to have halal foods. When one member of the right-wing party Sweden Democrats argued that by eating halal food Swedish school children would become a Muslim due to its "magic power", he was mocked by the local citizens (The Local 2015a). The government, through its representation Shivar Magdal (the veterinary inspector of the Swedish Board of Agriculture) and Sofia Wirlée (lawyer for the Swedish School Inspectorate), had said that every halal slaughter in Sweden met the same requirements with other slaughter and that eating halal foods in school was not considered a confession of faith (The Local 2015a).

In Sweden, the ban on the halal slaughter without hitting the animals is implemented and has been enacted in 1937. This ban is considered as the prohibition of religious freedom, even though both countries had supported religious freedom in their official documents. However, the actual ban on "traditional" halal food, which later prompted the religious leader to declare the different definition of halal foods in Denmark and Sweden is considered contradictory. It seems that Adrian's argument (2016) about the limitation of the actual exercise of religion happens in both countries. The Swedish government, even though having a similar ban, underlined a similar requirement for any other slaughter. The Swedish chose to enhance the discourses of "equality" and "similar treatment". Even the society (represented by the parents' complaint to the inspectorate) was using the idea of religion-neutral.

In 2007, Saudi's government was planning to fund the construction of the new mosque in Gothenburg (The Local Sweden 2007). Some suspicion regarding the Saudi's intention was raised, especially since the Brandbergen Mosque incident, which showed that there is a possible connection between mosque and radicalism. However, instead of focusing on how the outside actors funded several mosques, the media and politician in Sweden focused more on criticising the attack and arson against mosques that happened in December 2014 and January 2015.

As reported by the BBC News (2015b), the bomb, thrown at the mosque in Uppsala on 1 January 2015, was the latest of series of arson during the last week of 2014. The fires on Esloev and Eskilstuna and the patrol bomb at Uppsala prompted a response from the society and government. Instead of showing the differences and blaming the Muslim, the Swedish people organised anti-racism protests in Stockholm, Malmo, and Gothenburg. Slogans such as "do not touch my mosque" were seen during the rally by thousands of protesters. The government responded by condemning the attack. As stated by Culture and Democracy Minister, Alice Bah Kuhne, "Sweden should still be seen as a paradise for immigrants from different countries" (The Local Sweden 2015b). Even PM Stefan Löfven said, "In Sweden, no one should be afraid when practising their religion" (The Local Sweden 2015b). Instead of creating "us" against "them" 
discourses, the society and the Swedish government emphasised the Swedish identity of multiculturalism and tolerance.

\section{The Shifting of Swedish's Policy on Refugees}

On July $20^{\text {th }}, 2016$, Sweden ratified the Draft Law on the tightening and restriction of refugees and asylum seekers. The draft law sets restrictions on granting asylum permit to three years for refugees who have taken interviews and tests, and 13 months for refugees given temporary status. Besides, the government of Sweden tightened the policy of refugee family reunification and demanded a specific requirement for refugees bringing their families to Sweden. The draft law also eliminates the special protection category for refugees listed within the category. On January 4th, 2016, Sweden imposed a post on the border of Swedish used for identity checks to reduce the number of refugees and asylum seekers in Sweden (Migrationsversket 2016).

This condition is considered surprising since immigrants are one of the vital issues for Sweden. Amid the Syrian civil war, Sweden is categorized as a country that receives the most Syrian refugees. Based on the data from Eurostat, Sweden receives 190,000 refugees from 2011 to 2015, or about two per cent of the total population of Sweden. This influx of refugees turned Sweden to become one of the countries with the highest immigration rates. Moreover, the number of immigrant communities and their descendants are exceeding 10 per cent of the total population of Sweden. Such transformation is inseparable from the Swedish policy, which is considered quite liberal and open on the issue of immigrants. Sweden is known as the tops nation-state on the implementation of immigrant integration program and policy, which best meets the standards of the Migrant Integration Policy Index or MIPEX.

However, the transformation slowly brought Sweden into a population crisis that had never occurred before. The immense number of immigrants has turned the tide of Syrian refugees into external shock having spurred problems, such as the growing burden of the state and the emergence of resistant groups that reject Swedish immigration policy since it is considered too 'open'. Most immigrant refugees from the Middle East carried different racial, cultural, and religious identities with Swedish in which it often leads to cultural shock. Problems are increasingly complex as the number of immigrants increases and possibly creates a new crisis in Sweden which is somewhat influenced by the shifting factor of the population and cultural composition in the country. Eventually, the crisis leads Sweden to a political turn associated with the policy shift in terms of immigrant issues.

From 1968 to 1975, the government of Sweden formulated three main objectives of Swedish immigration policy, including equality, freedom of choice, and cooperation (Englund 2002). Such frameworks rendered the Swedish immigration policy as 'liberal' and 'soft' compared to its neighbours. In 2001, the Swedish Integration Policy focusing on equal values, responsibilities, and opportunities for refugees and asylum seekers in Sweden was drafted. This policy encouraged individuals to support and take parts in preserving the fundamental values of democracy; contributing in equal rights and opportunities for men and women; and preventing as well as fighting against ethnical discrimination, xenophobia, and racism towards the immigrants, refugees, and asylum seekers (Wiesbrock 2011). This constitution-based policy emphasizes equal rights, responsibilities, and opportunities for all, regardless of ethnic or cultural background; as well as the creation of a multicultural community with mutual respect and tolerance. In September 2008, Sweden revitalized the policy and identified several key aspects of refugee integration with Swedish, such as the emphasis on refugee orientation to 
entrepreneurship, school equality, language integration, and more higher education level. It is aimed at increasing labour supply and demand as well as creating quality and equality in schools (Wiesbrock 2011).

The open policy in Sweden has made the country a major destination and the recipient country for refugees and asylum seekers. Throughout 2013, Sweden continued to receive a high number of refugees compared to other EU country members. The number of individuals granted refugee permits increased during 2013 with more than 28,400 people being granted, representing an increase of $68 \%$ compared to 2012. The number of asylum seekers also increased significantly from 43,887 in 2012 to 54,259 in 2013, up nearly to 24 per cent. During the second half of 2013, the number of asylum seekers reached an average of about 5,900 individuals per month in which 30 per cent of the asylum seekers in that year were from Syria (Europe Union 2014).

Based on a growing collection of official and academic discourses, the central theme which evolves over the Swedish discourse on refugee issues before the refugee crisis is about Swedish perception of refugees. In this regard, the researchers found an official speech from Fredrik Reinfeldt, the Swedish prime minister from 2006 to 2014. In a speech, Reinfeldt (2010) said:

"I would also like to say that in the long run we create a better world this way, because we make it possible for people to escape war, death, and misery; and we have learned and we will show it once again that these are the people who will become a part of society and build Sweden together with us."

Similar pattern related to this point of view is raised by the Minister of Development, Migration, and Asylum Seekers, Jan O. Karlsson, who in 2010 stated, "... it is better to be a dynamic immigration country than a stagnating emigration country..." (Barnato 2015). Later, Reinfeldt also said in a speech to the EU Parliament in 2008, “... We must create political opportunities for those people who have made their way to Europe. Opportunities that allow them to quickly enter the labour market..."

Those three statements provide a pattern of discourse on how Sweden views immigrants and refugees; a refugee discourse as an entity that positively affects Sweden, and the discourse that perceives Sweden as an open and inclusive country. The head of the press unit at the Swedish Migration Agency, Fredrik Bengtsson, said in 2011 that, "... In Europe, Sweden is a key destination and recipient country for asylum seekers." The statement illustrates and demonstrates the self-understanding side of Sweden regarding refugee issues, namely as the main destination and country of refugee recipient.

Elite statements, which mapped Swedish discourse-related refugees, are also observable from the statement of the current Prime Minister Stefan Lofven. As he said in his speech in 2015, ".... must drastically increase its acceptance of resettlement refugees and Sweden, we shall do our part of that undertaking." Furthermore, Lofven also stated, "... We said, 'never again walls to discriminate one human being from another...”. Align to the idea, Lofven then argued: “... My Europe accepts people who run from war, in solidarity and collectively. My Europe does not build walls, we help each other when the need is great".

On September 6, 2015, at a manifestation in Stockholm to welcome asylum seekers, Prime Minister Stefan Lofven made a speech that refugee acceptance can never be the task of a single individual or organisation, but it is a national duty to be taken as part of the responsibility of the nation. When Lofven said, “... Sweden's welcoming of refugees is all of Sweden's responsibility as a nation," the choice of the term 'nation' 
and 'responsibility' indicates a unified understanding of the country manifested in the form of a very humanist policy for the refugees. This choice was followed by the statement of Lofven: "... thus that which is now a strain, will ultimately be an asset to Sweden." which also shows that refugees are part of Sweden, not a threat or potential threat. The use of the term 'asset' by Lofven also shows a positive view of Sweden towards refugees, albeit an instrumental one.

In academic discourses, a similar pattern emerges, and one of them is seen from Sveker Bjork (1997). He stated the immigration policy in Sweden could be characterized as a liberal policy, in terms of significant refugee acceptance, and contained various steps to create social inclusion of newcomers into Swedish society, and achieve greater economic and social equality between different ethnic minorities and most of the population. As Bjork (1997) said, “.... there existed a strong believe in Sweden that their national refugee policy was probably the most generous in the world".

To further deepen the argument about the perception of Swedish, it can be further constructed through discourse in the Swedish public sphere of understanding in terms of migration and refugees. In the main Swedish government website, there are several stories from various refugees and asylum seekers who succeeded in Sweden, and it is written, "... He chose Sweden because his sister was already living there at the time. She had touted the country's virtue as a humanitarian solace for immigrants" (Government of Sweden, 2016). Moreover, in the statement of one Swedish resident interviewed by the Swedish government regarding immigrants and refugees entering Sweden, the answer arising is that "Swedes are welcoming. We are warm and open to any immigrants that wanted to come here, and such is essential feeling to made them accepted into our community" (Government of Sweden 2016).

Such public statements repeated the pattern of the existing discourse at the elite level that Sweden is content with the arrival of immigrants and refugees. The repetition of discourses that emphasised inclusiveness, humanitarianism, acceptance, equal opportunity, and prosperity for migrants illustrates a dominant discourse on Swedish perceptions that view refugees not as threats, but as entities in need of help. It appears that there is an alignment of lines of thinking between Swedish elites, academics, and the public in terms of Swedish identity and their perceptions of refugees, which indicates that the dominant discourse in Sweden is the emphasis of the identity of the country as an inclusive and friendly humanitarian nation for refugees, immigrants, and asylum seekers.

In its development, there is a shift in refugee policy in Sweden that contrasts with its previous policy during a refugee crisis in Europe. On November 24, 2015, the Swedish government initiated a policy of restricting the number of asylum seekers and refugees, and was no longer granted permanent residence permits, but was granted only temporary residence permits (Migrationsversket 2016). Besides, on January 4, 2016, Sweden enforced a post on the Swedish border used for identity checks, and it is explicitly stated in the policy that the aim is to reduce the number of refugees and asylum seekers in Sweden. On top of that, the Swedish endorsed the draft law of restriction. Based on this, we argue that there is a shift in the discourse on refugees in Sweden that changes the way the country views refugees and immigrants. This shift is further studied using discourse analysis after enactment of the restrictive policy.

At the elite level, the shifting discourse is observable from the speech of the Prime Minister, who delivered his speech regarding immigrant restrictions and the construction of a guard post on the Swedish border in 2016. Lofven said that:

"During a two-month period last autumn, Sweden took in 80.00o people at 


\section{From Acceptance to "Othering": An Analysis of Swedish Changing Identity towards the Refugees and Muslim Minority Groups}

a rate that is equivalent to 25 million asylum seekers annually in the EU as a whole. This brought our reception system to the brink of collapse and, in the absence of working European solutions, it forced us to take unilateral action.”

By such a statement, Lofven argued that Sweden was overwhelmed by the influx of refugees who continued to enter Sweden. The tone that emerged is different from the Reinfeldt speech of 2014, which emphasises the impetus for Swedish society to continue helping refugees who enter Sweden. The use of the terms 'to the brink of collapse' and 'the absence of working European solutions' in his speech indicates a concern about the stability of Sweden with the emergence of a wave of refugees in the country. Furthermore, Lofven also stated that "it's time to act, to ensure control of our external borders.... and implement the redistribution of refugees within the EU" (The Government of Sweden, 2016). It appears that Sweden wants a change in the acceptance of refugees and asylum seekers and illustrates that refugees at one point are no longer considered a positive thing in the point of view of Sweden.

Regarding the policy of restrictions on immigrants, Lofven later said, in an interview and press conference with TT:

\footnotetext{
"We'll look at the question and our starting point is that we can't return to a situation like the one we had last year, that wasn't sustainable. But we're looking at the question and must also have a solution at EU level. Once again, we won't go back to a situation like last year"
}

The repetition of the terms 'we won't go to a situation like last year' illustrates a contrasting a picture of Lofven regarding his understanding of the issue of refugees. The Swedish situation of refugees and asylum seekers is considered as an 'unsustainable' situation, and this implies that refugees and asylum seekers are the source of such instability. This position is supported by the discourse emerging from various political and public literature, which has the same pattern of discourse. One of them comes from an article entitled "multikulturellt samhällsprojekt" in daily newspaper of Svenska Dagbladet in August 2016, which wrote, "It was politically naïve to believe that good intentions can prevent unavoidable tensions and conflicts lying in the project of multicultural society" (Svenska Dagbladet 2016). Anders Fogelklou, in his article in the daily newspaper of Dagens Nyheter, also has a similar viewpoint, "It is time for Sweden to align to a restrictive immigration policy, as it is inappropriate and dangerous to formulate foreign policy according to the considerations of morality" (Dagens Nyheter 2016). In the domestic political scene, the democratic party of Sweden in October 2016 at a press conference launched a series of plans in order to release an international campaign designed to warn refugees not to come to Sweden (The Local 2016). The head of the Democratic Party of Sweden, Jimir Akesson, stated, "We want, through advertisements in foreign newspapers, describe that the utopia they want to come to in Sweden no longer exists. Here, it's tent camps, winter and cold." By such statements, it shows that there is a similar growing pattern among the elites, political, and public discourses that at the praxis level begin to show the emergence of the refugee issue. In other words, there is an indication of a shift in rhetoric about refugees and asylum seekers in Sweden at the praxis level which the researchers mapped out shifts towards a negative understanding of the arrival of refugees and asylum seekers.

The revelation at the praxis level that gives rise to a different understanding of the refugee-related discourse in Sweden is visible from the emergence of an attack in the mosque in Stockholm on November 26, 2016. Attackers threw firecrackers, drew swastika symbols and wrote "kill Muslims" in the mosque (RT 2016). The attack is the second time after the burning of a mosque on January 17, 2016. Besides, during the year of 2015, 13 attempts of assault and vandalism against the asylum seekers in 
Sweden were recorded (The Local 2016).

Following the argument of Hansen (2006) related to idea and material, the case indicated the shift of discourse developed in Swedish society. In other words, the changing basic idea and rhetoric of refugees amidst the emergence of refugees' wave to Sweden is the reason of a shift in the understanding of Swedish society regarding refugees and also the cause of the attack.

The alignment of ideas and practices at the Swedish community and elite political level illustrates the understanding and perception of refugees' potential threats which represent strong indication that there is a significant shift in understanding. Associating with the analysis of the discursive structural shift by Weaver (2002), we see that the shift in understanding takes place in the surface level, which is related to political manifestations. This is inseparable from the statements at the elite level, as well as the practice of policies that have not explored the aspect of identity. The pattern of statements at the elite level indicates a shifting perception, but it is still dominant only within the political statement. So, it can be concluded that there has been no further process of differentiation and real othering.

Nevertheless, surprising indications of a further shift are seen in the public sphere. This further shift is observable in the statements and rhetoric which begin to associate with a more fundamental identity. The case of the mosque attack in Stockholm not only indicates political rhetoric but also led to religious identity aspect. So, there are strong indications that there has been a shift in a more fundamental understanding at the level of Swedish society.

\section{Conclusion}

One main point to take from this study is that Sweden, as one of the main targets in Europe for refugees and asylum seekers, is currently experiencing challenges and shocks, both on a political and discursive level. The coming wave of refugees has caused a discursive shock in Sweden, and this is reflected in a shift in understanding of Swedish society and elite regarding refugees and asylum seekers. The policy of restrictions on immigrants and guard posts on the Swedish borders that was enacted in 2016 is a political realisation of this shifting understanding, even though this shift is still at the surface level. However, indications that a further shift can begin with the emergence of a public discourse that further strengthens the 'othering' process between Swedish society and the coming immigrants.

Concerning this and the fact that this issue is still ongoing until the article is written, this can be a consideration for further research that has the potential in exploring further answers concerning the discourse of refugees in Sweden. In addition, further research to be conducted should pay attention to the caveat within this study; one of which is the focus on discursive structures at the foreign policy level makes the elites and policymaker more significant and rule out marginal discourses, such as popular discourse and local-language daily newspaper, which may provide a more comprehensive portrayal of discursive structures. Furthermore, Sweden, even though in some respect still prohibit the full exercise of religious freedom (in the issue of halal foods), but the way they portrayed the discourse on Muslim communities in Sweden underlined the idea of acceptance, secularism, and multiculturalism. The discourses on the attack on several mosques showed how both government and society in Sweden had higher recognition towards the Muslim religious communities. At best, this kind of policies will drive the idea of greater integration and total equality between Muslim 
communities and other groups in Sweden. At worst, it might divide Swedish societies into many groups with different perceptions towards Muslim. As Steiner (2015) argued, different kind of rifts happened in Sweden, which involve Christian, liberal, neonationalist, and fundamentalist. Their position towards Islam and religious freedom will be interesting future research.

\section{References}

\section{Book and Book Chapter}

Adrian, M., 2016. Religious Freedom at Risk: The EU, French Schools, and Why the Veil was Banned. Cham: Springer International Publishing.

Ashley, R., 1996. "The achievements of post-structuralism", in S. Smith, K. Booth, and M. Zalewski (eds.), International Theory: Positivism and Beyond. Cambridge: Cambridge University Press.

Burke, A., 2006. "Identity/difference", in M. Griffiths (ed.), Encyclopedia of International Relations and Global Politics. London: Routledge.

Campbell, D., 2007. "Poststructuralism”, in T. Dunne, M. Kurki, and S. Smith (eds.), International Relations Theories: Discipline and Diversity. Oxford: Oxford University Press.

Englund, C., 2002. Migrants, Minorities and Employment in Sweden: Exclusion, Discrimination and Anti-Discrimination. Stockholm: European Monitoring on Racism and Xenophobia.

Hansen, L., 2006. Security as Practice. New York: Routledge.

Hansen, L., 2012. "Discourse Analysis, Post-Structuralism, and Foreign Policy", in S. Smith, A. Hadfield, \& T. Dunne (eds.), Foreign Policy: Theories, Actors, Cases. Oxford: Oxford University Press. $2^{\text {nd }}$ Edition.

Lamont, C., 2015. Research Methods in International Relations. London: SAGE.

Sakaranaho, T., 2006. Religious Freedom, Multiculturalism, Islam: Cross-Reading Finland and Ireland. Leiden: Brill.

Urrestarazu, U.S., 2015. "Identity' in International Relations and Foreign Policy Theory”, in G. Hellmann \& K.E. Jørgensen (eds.), Theorizing Foreign Policy in a Globalized World. Hampshire: Palgrave Macmillan.

Waever, O., 2002. "Identity, Communities and Foreign Policy: Discourse Analysis as Foreign Policy Theory", in L. Hansen \& O. Waever (eds.), European Integration and National Identity: The Challenge of the Nordic states. London: Routledge.

\section{Journal and Online Journal}


Agius, C., 2013. "Performing identity: The Danish cartoon crisis and discourses of identity and security", Security Dialogue, 44(3): 241-258.

Belsey, C., 1994. "Postmodern Love: Questioning the Metaphysics of Desire", New Literary History, 25(3): 683-705.

Brubaker, R. dan F. Cooper, (2000). "Beyond "identity"”, Theory and Society, 29(1): 1-47.

Campbell, D., 1990. "Global Inscription: How Foreign Policy Constitutes the United States”, Alternatives: Global, Local, Political, 15(3): 263-286.

Holzscheiter, A., 2014. "Between Communicative Interaction and Structures of Signification: Discourse Theory and Analysis in International Relations", International Studies Perspectives, 15(2): 142-162.

Knudsen, K., et al., 2008. "The Burden of Identity: Responding to Product Boycotts in the Middle East”, Journal of Business \& Economics Research, 6(11): 17-26.

Kowert, P., 1998. "National identity: Inside and out”, Security Studies, 8(2-3): 1-34.

Wiesbrock, A., 2011. "The Integration of Immigrants in Sweden: A Model for the European Union?”, International Migration, 49(4): 48-66.

Miliken, J., 1999. "The Study of Discourse in International Relations: A Critique of Research and Methods", European Journal of International Relations, 5(2): 225-254.

Steiner, K., 2015. "Images of Muslims and Islam in Swedish Christian and secular news discourse", Media, War \& Conflict, 8(1): 20-45.

\section{Online Article}

ABC News, 2015. "Anti-Immigrant Protests Grow as Thousands of Refugees Flood Europe" [online]. in http://abcnews.go.com/International/anti-immigrantprotests-grow-thousands-refugees-flood-europe/story?id=35888428 [accessed 20 January 2016].

Barnato, K., 2015. "Counting the cost of Europe's migrant crisis", $C N B C$, [online]. in http://www.cnbc.com/2015/o9/18/counting-the-cost-of-europes-migrantcrisis.html. [accessed 22 January 2016].

Baroud, R., 2006. "Punishing Denmark, the wrong enemy", Asia Times Online, [online] in http://www.atimes.com/atimes/Middle_East/HBo2Ak02.html [accessed 3 January 2016].

BBC News, 2015a. "From Turkey to Sweden: Syrian migrant's perilous journey", available in http://www.bbc.com/news/world-europe-34118978 [accessed 19 January 2016]. 
From Acceptance to "Othering": An Analysis of Swedish Changing Identity towards the Refugees and Muslim Minority Groups

BBC News, 2015b. "Sweden protest after three mosque fires in one week", [online] in http://www.bbc.com/news/world-europe-30658482 [accessed 24 January 2016].

European Union, 2014. "EU and Refugee Crisis", [online]. in http://publications. europa.eu/webpub/com/factsheets/refugee-crisis/en/. [accessed 24 November 2016].

Financial Times, 2006. "Timeline: How the cartoon crisis unfolded", [online] https://www.ft.com/content/d3oboc22-96ee-11da-82b7oooo779e2340\#axzz3OG6ux286 [accessed 3 January 2016].

Freedom House, 2015. "Sweden", [online]. in https://freedomhouse.org/report/ freedom-world/2015/sweden\#.VecIMPmqpBc [accessed 24 January 2016].

Igler, G., 2015. "The True Cost of Europe's Muslim “Enrichment”", [online] in http:// www.gatestoneinstitute.org/6915/europe-muslim-enrichment. [accessed 22 January 2016].

LA Times, 2015. "Which countries are taking in Syrian refugees?" [online]. in http:// www.latimes.com/world/europe/la-fg-migrants-scorecard-20150908-story. html. [accessed 21 January 2016].

Lofven, S., 2014. “Stefan Lofven Inaugural Speech” [online] in http://sverigesradio.se/ sida/artikel.aspx? programid $=2054$ \&artikel $=5981869$. [accessed 28 November 2016].

Lofven, S., 2016. "Statement of Government Policy 13 September 2016" [online] in http://www.government.se/speeches/2016/o9/statement-of-governmentpolicy-17-september-2013/. [accessed 25 November 2016].

Migrationsversket, 2016. "EMN Policy Report 2013" [online]. in http://www. emnsweden.se/download/18.2d998ffc151ac3871591716o/1476868087277/ Policy+Report+Sweden_Final_2013.pdf. [accessed 24 November 2016].

Minority Rights, 2015. "Country Profile: Sweden” [online] in http://minorityrights. org/country/sweden/ [accessed 19 January 2016].

NPR, 2015. "A Coveted Destination by Migrants, Sweden Imposes Border Controls", [online].in http://www.npr.org/2015/11/13/455862590/a-coveted-destinationby-migrants-sweden-imposes-border-controls [accessed 20 January 2016].

Reinfeldt, F., 2013. "Prime Minister Fredrik Reinfeldt's speech at UN General Assembly 2013" [online]. in http://www.swedenabroad.com/en-GB/Embassies/ Ankara/Current-affairs/News/Prime-Minister-Fredrik-speech-at-UN-GeneralAssembly-2013-sys/. [accessed 28 November 2016].

RFE/RL, 2012. "Swedish Muhammad Cartoonist Says 'World' Created Controversy" [online]. in http://www.rferl.org/content/swedish-muhammad-cartoonistsays-world-created-controversy/24769811.html [accessed 19 January 2016]. 
Sputnik News, 2015. "Destination Sweden: Tougher Rules and Minimum Refugee Resettlement Levels" [online]. in https://sputniknews.com/ europe/201512011031047305-sweden-refugee-rules-resettlement-planchange/ [accessed 20 January 2016].

Svenska Dagbladet, 2016. "Sveriges modell för välfärden är i kris" [online]. in http:// www.svd.se/sveriges-modell-for-valfarden-ar-i-kris/om/debatt [accessed 25 November 2016].

Svenska Dagbladet, 2016. "Mer krävs för att stoppa radikalisering” [online]. in http:// www.svd.se/mer-kravs-for-att-stoppa-radikalisering/om/hotet-mot-sverige. [accessed 25 November 2016].

Swedish Institute, 2015. "10 fundamentals of religion in Sweden" [online]. in https:// sweden.se/society/10-fundamentals-of-religion-in-sweden/ [accessed 23 January 2016].

Taylor, Pelle Neroth, 2015. "Sweden's Immigration Crisis: The emergence of a political and cultural crisis" [online]. in https://www.brugesgroup.com/media-centre/ comment/37-comment-and-analysis/1114-sweden-s-immigration-crisis. [accessed 25 May 2016].

The Economist, 2010. "Bombs in Sweden: Terror comes to Stockholm" [online]. in http://www.economist.com/blogs/newsbook/2010/12/bombs_sweden. [accessed 23 January 2016].

The Guardian, 2016. "Tensions rise in Germany over handling of mass sexual assaults in Cologne" [online]. in http://www.theguardian.com/world/2016/jan/o6/ tensions-rise-in-germany-over-handling-of-mass-sexual-assaults-in-cologne. [accessed 17 January 2016].

The Independent, 2016. "Cologne sexual assaults: Anti-Muslim group Pegida plans to stage rally in city after attacks" [online]. in http://www.independent.co.uk/ news/world/europe/anti-muslim-pegida-rally-cologne-sex-attacks-a6801396. html [accessed 17 January 2016].

The Local Sweden, 2007. "Building set to start on Saudi-funded Mosque" [online]. in http://www.thelocal.se/20071106/9021 [accessed 17 January 2016].

The Local Sweden, 2009. "Muslim group: "Make halal slaughter legal"” [online]. in http://www.thelocal.se/20090331/18576 [accessed 24 January 2016].

The Local Sweden, 2013a. "Angry parents spark halal school lunch spat" [online]. in http://www.thelocal.se/20131011/50732 [accessed 23 January 2016].

The Local Sweden, 2013b. "Agency backs halal meat in school lunch spat", available at http://www.thelocal.se/20131123/halal-meat. [accessed 24 January 2016].

The Local Sweden, 2014. "Reinfeldt calls for tolerance to refugees" [online]. in http:// www.thelocal.se/20140816/reinfeldt-calls-for-tolerance-to-refugees [accessed 25 November 2016]. 
The Local Sweden, 2015a. "You become a Muslim if you eat halal meat" [online]. in http://www.thelocal.se/20150707/you-become-a-muslim-if-you-eat-halalmeat. [accessed 22 January 2016].

The Local Sweden, 2015b. "Sweden rallies after trio of mosque fire attacks" [online]. in http://www.thelocal.se/20150102/mosques-on-high-alert-after-arson-attacks. [accessed 25 January 2016].

The Local Sweden, 2016. “Could Sweden's border controls soon be lifted?" [online]. in http://www.thelocal.se/20160929/could-swedens-border-controls-soon-belifted. [accessed 28 November 2016].

The Local Sweden, 2016. "Nationalists to run global anti-refugee campaign" [online]. in http://www.thelocal.se/20151015/swedish-nationalists-to-run-anti-refugeeads-abroad. [accessed 28 November 2016].

The Local Sweden, 2016. "Two arson attempts on Swedish refugee centres" [online]. in http://www.thelocal.se/20150815/arson-attack-on-swedish-child-refugeecentre. [accessed 28 November 2016].

The Local Sweden, 2016. "West Sweden mosque hit by possible arson attack" [online]. in http://www.thelocal.se/20160117/western-sweden-mosque-destroyed-inpossible-arson-attack [accessed 28 November 2016].

Turkish Weekly, 2007. "Swedish Muslims and the cartoon crisis" [online]. in http:// www.turkishweekly.net/2007/09/07/news/swedish-muslims-and-thecartoon-crisis/ [accessed 23 January 2016].

\section{Others}

Agra Europe, 2006. "Cartoon row hits Danish poultry exports", Agra Europe 2195, 17 February 2006.

Borisenko, E, 2005. "Discourse on Immigration in Swedish Mass Media", Master's Thesis, Department of Management and Economics, Linköping University, Sweden.

Brady, H, 2012. "The Schengen Crisis in the Framework of the Arab Spring”, Opinion Pieces, Centre for European Reform.

Gometz, J., 2016. "Refugee Biopolitics: A discourse analysis of the Swedish government's recent shift in the speech on refugees", Bachelor Thesis, School of Global Studies, University of Gothenburg.

Lindroth, M. and M. Vertiachykh, 2016. "The Unwanted: negotiating the refugeehood in Sweden", Bachelor Thesis, Department of Social and Psychological Studies, Karlstad University. 